\title{
CONTEMPORARY MUSIC FESTIVALS IN LITHUANIA: FROM ACTION TO CONCEPT
}

\author{
VITA GRUODYTÉ
}

\begin{abstract}
At the time of the Independence of the 1990s Lithuanian music was marked by a short but very important period which saw the rise of new multidisciplinary approaches, namely happenings, actions or performances. This new wave, initiated by young composers and musicologists, attempted to delineate the break with the aesthetics imposed by the ideological Soviet system, even if that was not valid any longer at that time.

Keywords: Lithuanian music, happening, action, performance, contemporary music festivals.
\end{abstract}

This article was written as a part of the project «Music of Change: Expression of Liberation in Polish and Lithuanian Music Before and After 1989» (Nr. P-LL-18-213), funded by the National Science Centre (Poland) and Lithuanian Research Council (Lithuania).

We must admit that throughout the whole period after the restoration of independence in 1991, the Lithuanian music scene did not experience any significant aesthetic turn. During the last years of the Soviet era Lithuanian music was far from any kind of a stylistic dead end as the majority of the progressive composers, for example, Bronius Kutavicius, Feliksas Bajoras, and Osvaldas Balakauskas, had already formed their musical language in the 1970s and the younger ones were actively experimenting with new forms of composition from the beginning of the 1980s.

However, political change undoubtedly had an impact on everyone, and the consequences were inevitably reflected in the music scene through various forms: if not through the emergence of new alternatives, then through certain signs of a new artistic identity that were supposed to signify and articulate the political change in society.

\section{Collective actions}

After looking around the spectrum of the musical scene of the time it becomes clear that this period was ripe with collective activity rather than individual choices, hence the function of rupture was most evidently performed not by separate works but by collective artistic actions. In this respect, non-academic music festivals initiated by young composers provided the best niche for this kind of creative expression. The list of festivals is as follows:

- The Youth Festival «Chamber Music Days» [Jaunimo kamerinés muzikos dienos] in Druskininkai (from 1985) founded by composer Ričardas Kabelis;

- The Festival of Creative Youth [aunimo kūrybos festivalis] in Panevėžys (1987-1988) which has later become The Festival of Musical Action [Muzikinio veiksmo festivalis] as well as The Avant-garde Art Festival [Avangardinių menu festivalis]) in Panevėžys and Vilnius (1989-1997) founded by composers Liutauras Stančikas and Snieguole Dikčiūtė;

- Free Sound Sessions [Laisvojo garso sesijos] taking place at the Lithuanian Conservatory (Vilnius), Panevėžys and Kaunas (1987-1988) organized by composers Tomas Juzeliūnas, Arūnas Dikčius and musi- 
cologist Giedrius Gapšys;

- Happening Seminars in Anykščiai and Nida (AN-88, AN-89, NI-90) organized by composer Gintaras Sodeika;

- and The New Music Festival [Naujosios muzikos festivalis] in Kaunas House of Architects $(\mathbf{1 9 8 7}, \mathbf{1 9 8 8}$, 1989) founded by composer Vidmantas Bartulis.

The very titles of these festivals were already hinting at their content: «youth», «new music», «happening», «free sound», «musical action», «avant-garde art». Even though the festivals were happily attended by mature and established composers and musicologists, these epithets were referring to the initiatives of the youth.

At the end of the Soviet occupation, Lithuanian music was not deadlocked, but it didn't have every opportunity to try out freely the non-conventional forms and acoustic experiences. The spontaneous character, the immediacy of execution, the collective actions of performers and the active role of audiences have helped to give priority to the experimentations of concepts and ideas instead of aesthetics or material concerns. So, happenings and performances were the most appropriate way for Lithuanian composers and musicologists to mark that period and to participate instantly in political and aesthetic changes.

\section{Questioning the notion of artwork}

The majority of the pieces played during the festivals still retained the conventional forms, but some of them already reflected the changing attitude towards the creative process (which was considered as a certain open workshop) as well as towards the musical piece itself (as a more or less spontaneous, interdisciplinary performance with the uniqueness of the happening).

The intermediary position was taken by the pieces that had theatrical and/or absurd elements; they were different from actions and happenings by being less spontaneous and by not turning the audience into participants of artistic action. However, their goals were similar: questioning the notions of the artwork, performance space and the reaction of the public. Within the Lithuanian context, things like instruments, musical scores and the relation between music and other disciplines were being treated in unprecedented ways. The audience that was lucky to have been engaged in these artistic experiments not only had a chance to reconsider its understanding of ideology-free contemporary art but also helped the young artists to assess their ideas.

For the young creators of the time, the genre of performance was like a certain tool that helped them find answers to pertinent questions such as:

- What are the limits of creative freedom after the restrictions of ideological censorship have been abandoned?

- What are the boundaries between the artistic disciplines?

- Can the verbal, visual and musical gestures have analogous capabilities of site-specific expression, and can they collaborate and form a unified content?

- What is an artwork itself?

\section{Non-formal spaces}

As far as spontaneous artistic action is concerned during the Soviet era the artistic environment did not exist. Art was legally bound to designated spaces, and its purpose was to reflect the specific aesthetics regulated by the totalitarian system. However, regardless of these restrictions, musical context as a whole was far from monolithic: if we were to analyze the situation of Lithuanian music during the second part of the $20^{\text {th }}$ century we would notice that artists lived in a stratified reality, where some were creating ideology-friendly art, others were cautiously critical towards the ideology, while the rest were trying to create music that both reflected on national identity and encompassed the signs of modern and, later, postmodern eras in the West.

During the times of the Lithuanian Independence Movement in the late $80 \mathrm{~s}$, young musicians were not only able to assimilate the public space anew, but they also felt free to rethink their whole environment aesthetically by discarding its neutrality, getting rid of the ideological restrictions, and thus turning statics into dynamics. The figure of an artist had acquired new functions and became, to use Frank Popper's insight, «more of a mediator rather than creator», while an artwork lost its previous forms be- 
cause «active participation on the part of a spectator stipulated the disappearance of a traditional art object» [1]. Reactive (in the sense of their realization) happenings, performances, and actions were turned into artistic heralds of independence precisely because of their abilities to express spontaneous reactions to the changing times.

The fact that artists left academia for a non-formal space signified not only conscious opposition towards institutional and official art but also the affirmation of the importance of the historical change that was happening at the time. What was specific to Lithuania and other Soviet Bloc countries, was that this was an expression of an opposition not only towards certain stylistic paradigms, the academization of art or the art tradition as such - the very same concerns were also tackled in the West - but (and this is crucial!) it also marked opposition towards the ideologization of art.

The prevailing ideology was easily rejected by young artists because it was not part of their choice, nor was it the choice of the previous generation; it was artificially imposed from outside as an aesthetically limited compositional thinking — «Genghis Khanstyle, fascist, normative idealism» (as musicologist Vilija Aleknaite wrote in 1989) [2] — that the majority of composers has continuously been trying to circumvent for decades.

After leaving the institutional environment of Vilnius where development was restricted by governmental censorship, cultural initiatives found new possibilities in the informal peripheries of Druskininkai, Panevezzys, Anykščiai, and Kaunas, where artistic and non-artistic spaces were not predetermined by strict control. This allowed for various symbolic places of art distribution to emerging - a factor that fostered the implementation of new ideas and opened up new perspectives for understanding how art should function. In the physical sense, the establishment of ephemeral and short-term art spaces were necessary for the actualization of the essential fact of the time - namely, the dissociation from a hierarchical system regulated by censorship - and the implementation of its critical assessment.

\section{From action to concept}

The phenomenon of artistic action is a hard one to analyze because it can be both spontaneous and predetermined. However, what is important here is that at the time the very object of art - an artwork - became deprived both of its objectifiable value (it could not be bought nor sold) and its substance, because the aesthetic value became substituted with a concept (and artistic performance was the only way through which it could be realized).

«The Sovietism of the 80 s was one huge shabby bag with countless holes from which absolutely everything was leaking. The fact that everyone was taking advantage of that had an enormously joyous effect. No contemporary canons or standards can do justice in describing it because it was an era of noneconomic relations. We were isolated within the territory of Lithuania but we were not seeking to export our ideas and turn them into some commodities. That was simply impossible» (Šarūnas Nakas) [3].

This era marks a transitory period in Lithuanian history («we found ourselves caught in some sort of a transition» [4]) - a transition from the State as a sovereign commissioner and customer of art to the world of free markets where an artwork became a commodity. That was the reason why young artists of that time became more like a spatio-temporal experience because the material used in artistic action acquired the status, not of a form or content, but that of experience: this is precisely what can be called a materialization not of an artistic object, but that of the artistic concept. «At that time The Festival of Anykščiai purposefully engaged in a conceptual discourse with its audience, and that was exactly what the audience needed» (A. Dikčius) [5].

The sign that Lithuanian music came within the proximity of the artistic processes of the West was that it had turned towards its inner purely aesthetic resources instead of fighting with the external ideological imperatives. The conceptual dimension of the performances of that period was firmly established and it had become clear that art as the embodiment of aesthetic value finally found its main justification in the eyes of the public. 
The period of interdisciplinary events in Lithuania did not result in a substantial gamut of structurally finished projects that would enable us to highlight the independent trends, like Land art or Body art that emerged in the West. These trends were developed more by Lithuanian visual artists - groups such as Green Leaf (Žalias Lapas) and Post Ars. However, there were hints among composers as well. For example, «The Garden of Oracle» («Orakulo darželis»), «The Opening of the Sixth Valve» («Šeštojo klapano atidarymas») and «Rockabye Stones» («Liūliuojantys akmenys», AN-88) were happenings that transformed their environment into an artistic space, while in works like «The Last Supper» («Paskutinè vakarienè») or «Bureaucratic Hitch-hike» («Biurokratinis autostopas») the body was used as the central element of action. However, the sound remained a key factor in the majority of the site-specific projects by composers that employed the synthesis of disciplines, elements of musical theatre or political caricature. Their aim was not to create and purify certain syncretic tendencies, but to test the forms of artistic synthesis that would reveal the abilities of the forms and materials of parallel disciplines to be absorbed through sonorous thinking. "Was it evident that the majority of the participants were musicians?»asked Austeja Nakienè when reviewing the First Seminar in Anykščiai. «Yes, because the majority of happenings were constructed according to the principles of musical composition and the actions were arranged according to strict timing. Performers had to join in time, play their parts and finish on time, as if they were in a musical ensemble or a small orchestra» [6].

As the least restricted forms of artistic expression that came from the West, happening and performance turned out to be the most suitable for the time of Independence. They enabled adequate reflections on artistic intentions and technical possibilities of the time: they inspired spontaneity and uniqueness, eclectics and interdisciplinarity, the simplicity of expression (which is one of the characteristics of the Lithuanian mindset), the search for new sounds, and more intimate relation with the audience.
The forms of Lithuanian performance demonstrate a certain historical continuity of this genre: onomatopoeic poetry or synthetic single-idea actions would refer to futurism; utilization of real space and real objects - to Russian constructivists; concern with the creation of a new society through artistic forms, expressive primitiveness, the insistence on tabula rasa and linguistic purification through, again, onomatopoeia - to Dadaism; non-provocative search for spatial possibilities - to Bauhaus aesthetics. Surrealism with its perfected theatrical forms remained the least close to the tradition of Lithuanian performance art (with an exception of, perhaps, some of the opuses by Vidmantas Bartulis). Therefore, we might argue that the majority of these works had returned to their origins and held on to the ideas of the early performances of the $20^{\text {th }}$ century.

\section{Social role}

Happenings and performances allowed artists to rethink and - with the help of improvisational forms - articulate the changes not only in the aesthetic realm but also in terms of the social role of an artist. During the Soviet era, we had artists who either performed or imitated their ideological function or remained neutral. With the coming of independence this state of events was disturbed and, inevitably, the social role of an artist shifted. Those who lost their status of a well-paid functionary of the system were forced to find another - undoubtedly more dynamic and innovative - form of existing in society. The change also impelled artists to become the creators of new values on the crossroad of two opposing trends: tradition (national identity) and the contemporary mindset (Western artistic practices). Each and everyone had to reconsider their creative motivations. Therefore, by establishing new ethical landmarks this period did not, however, change aesthetic tendencies: contrary to the visual artists, none of the Lithuanian composers remained faithful to this transitory period longer than was needed, and none of them capitalized on it in any significant way. Arūnas Dikčius described this phenomenon rather succinctly: 
«Truth be told, we all admired the Fluxus-style ways of life and creativity. However, all the composers and musicologists of the time chose academic work. $<\ldots>[W]$ e told each other that the essence of our work is not just happenings, but something more. $<\ldots>$ Unfortunately, now I am unable to remember what we meant by saying that and what this «more» was supposed to signify. <..> All these AN Festivals were like some sort of Fluxus sanatoriums for the improvement of our creative health» [7].

During Soviet times the practice of artistic action did not exist at least because the self-expressive spontaneity of these actions was incompatible with the artistic policy regulated by state censorship. However, Lithuania still held the memory of the modernists of the interwar period, and the practices of Western music were also known - at least in the form of information - during the whole postwar period thanks to the musicians who had a chance to travel around the world, and - last but not least - thanks to the correspondence that escaped censorship. Audiences were acquainted with the work of the Fluxus founder George Maciunas, partially thanks to his correspondence with Vytautas Landsbergis. Therefore, it is rather logical that during the Druskininkai Festival «89 Mačiūnas〉 letters to Landsbergis were published in the Young Music brochure, and the Druskininkai Festival $₫ 91$ was entirely dedicated to the $60^{\text {th }}$ anniversary of Mačiūnas〉 birth. In her review of the aforementioned festival, musicologist Živilè Ramoškaitè wrote:

Everything seemed to be clear in the description, however in fact... there were instances of total misunderstanding. Some examples: during the discussion everyone was sticking to their song by totally disregarding everyone else - a real cacophony; ...or, say, water swims in the swimming pool by itself as the «swimmers» are skulking in some recreational base, etc. If you want some evaluation of all this, a remark made by one freshman might come in handy: «I didn't like the most of it, but in general I liked it» [8].

From the perspective of time, such critique (bordering on desperation) looks almost like the highest compliment and proof that the festival was a success because it reflected the zeitgeist so effectively.
This situation only affirms the polyphony of the different values and views that existed simultaneously at the time. We see it in the reminiscence of Arūnas Dikčius who recalls the artistic action by «Oracle's Garden» in Anykščiai:

[W] hile demonstrating the new almanac published by our young philologists, professor V[ytautas] Landsbergis gave an evaluation of our action: «Here's what your colleague philologists accomplished while you were tangling your little bells». At the time I was impressed by this remark, I felt a gust of pathos of civil affairs. A new tone. But now I think - maybe it wasn't worth it [9].

\section{0 years later}

The period of the 90s has sown some seeds. Around 2 decades later, in 2008, another youth festival appeared, New Opera Action, which can be considered as the most innovative contemporary music festival in Lithuania. It was also initiated by a group of young creators, sometimes still students: composers, scenographers, singers, directors, conductors, choreographers, etc. This new framework invites young composers, once again, to experiment with the hybrid forms, and to further erase the borders between genres. Among their concerns we can find the same axes of reflection as in 1990, that is: using non-formal spaces, questioning the notion of the artwork and setting up new ideas through collective actions.

We note here an obvious desire to take the opera out of its institutional and conventional framework. We see the desire to loosen the constraints of academic codes and to make not just an aesthetic turn, but also a fundamental one. Their goal is to preserve the freedom to move in different spaces, to adapt spaces to ideas and not the reverse.

Just by its name New Opera Action emphasizes a junction between opera and action, and above all, between the opera and its time. Short or very short operas such as nano operas make it easier to test and renew ideas and their components. We note the individualization of the role of the performer, as in musical theatre, but at the same time a search for homogeneity between different constituent parts: music, sing- 
ing, dance, new technologies... The composer can be at the same time the interpreter, the director, the scenographer and/or the choreographer. Such conditions, which facilitate the mastery of the different disciplines, allow the creator to express more freely and authentically his artistic temperament and his stylistic personality. The architectural space appears as an active, organic element, as an extension of the general idea of the work, sometimes as its unique «envelope», not adaptable to other creations.

By transgressing the boundaries of the genre, NOA has upset the codes of Lithuanian opera. Without seeking any institutional support, it has invented new perspectives. In fact, the founder of this movement, Jonas Sakalauskas, himself an opera singer and composer, makes opera work like a start-up, with the multiplication of directions and forms of activities, collective inventions, or structures with little or no hierarchy. Theatre for Sakalauskas is a cultural platform that reacts actively to his environment: it has taken a cultural and social form.

The political and social criticism, the current-oriented view of the first festivals of the 90s, echoes some of the NOA's creations. Especially with the works of Lina Lapelytè, Vaiva Grainytè, Rugilè Barzdžiukaitè. Their first joint opera, «Have a Good Day» pointed the everyday working conditions of supermarket cashiers, the second one, «Sun \& Sea», distinguished by the Golden Lion at the Venice Biennale in 2019, criticized the present ecological situation. This distinction was surely awarded not only for the originality of the performance but especially for its committed aspect, which denounces the general weariness in front of imminent ecological disaster.

The multidisciplinary approach can be considered as a common axis linking festivals of young composers since the Independence of Lithuania. On the other hand, since the first festivals, progress has been made towards a "professionalization» of the domain:

1. In the 90s the collective actions were stopped to give way to the individual career of the composers. Now we see that the collective projects or performances initiated by NOA, are perfectly compatible with individual careers.
2. The 1990s were marked by spontaneous actions in the short term without the worries of tomorrow, because nobody knew, for financial or political reasons, whether this or that festival would continue the following year. The establishment of a formal framework, that is to say, the production house, named «Operomania», that frames the NOA, allows not only the emergence but also the continuity and durability of such projects.

3. The performances and actions of the 1990s were, overwhelmingly, «dematerialized», that is, they do not exist as an artefact that can be «transmitted» or repeated on another occasion. Whereas the most successful creations of NOA have a long life. And at the same time, they preserve the nature of their performance, which means, they are not finished. For example, «Sun \& Sea», is a flexible performance opera, which changes and adapts to various conditions while preserving its quintessence.

To sum up, the period of artistic action in the $90^{\text {th }}$, helped Lithuanian music to escape the system, by giving a sense to the political changes and thus enlarging significance and enriching the language of contemporary music. This period generated, first of all, the active, conscious and committed artistic position towards the world.

\section{Summary}

During the last years of the Soviet era, Lithuanian music was far from any kind of a stylistic dead end, as the majority of the progressive composers had already formed their musical language in the 1970s, and the younger ones were actively experimenting with new forms of composition from the beginning of the 1980s.

However, political change undoubtedly had an impact on everyone, and the consequences were inevitably reflected in the music scene through various forms: if not through the emergence of new alternatives, then through certain signs of a new artistic identity that were supposed to signify and articulate the political change in society.

At the end of the Soviet occupation, Lithuanian music was not deadlocked, but it didn't have every 
opportunity to try out freely the non-conventional forms and acoustic experiences. The spontaneous character, the immediacy of execution, the collective actions of performers and the active role of audiences have helped to give priority to the experimentations of concepts and ideas instead of aesthetics or material concerns. So, happenings and performances were the most appropriate way for Lithuanian composers and musicologists to mark that period and to participate instantly in political and aesthetic changes. In this respect, non-academic music festivals initiated by young composers provided the best niche for this kind of creative expression.

As far as spontaneous artistic action is concerned during the Soviet era the artistic environment did not exist. Art was legally bound to designated spaces, and its purpose was to reflect the specific aesthetics regulated by the totalitarian system. During the times of the Lithuanian Independence Movement in the late 80 s, young musicians were not only able to assimilate the public space anew, but they also felt free to rethink their whole environment aesthetically by discarding its neutrality, getting rid of the ideological restrictions, and thus turning statics into dynamics.

The sign that Lithuanian music came within the proximity of the artistic processes of the West was that it had turned towards its inner purely aesthetic resources instead of fighting with the external ideological imperatives. The conceptual dimension of the performances of that period was firmly established and it had become clear that art as the embodiment of aesthetic value finally found its main justification in the eyes of the public.

The period of artistic action in the $90^{\text {th }}$, helped Lithuanian music to escape the system, by giving a sense to the political changes and thus enlarging significance and enriching the language of contemporary music. This period generated, first of all, the active, conscious and committed artistic position towards the world

\section{References}

1. Frank Popper, Art, action et participation, Paris: Klincksieck, 1985, p. 13.

2. Vilija Aleknaitė, «Atoveiksmio punktyras lietuvių muzikoje», Jauna muzika (Edited by Ričardas Kabelis), Vilnius, Lietuvos kompozitorių sąjunga, 1989, p. 13.

3. Kęstutis Šapoka, „Pokalbis su Šarūnu Naku», (Ne)priklausomo šiuolaikinio meno istorijos, (Edited by Vytautas Michelkevičius, Kęstutis Šapoka), Vilnius: LTMKS, 2011, pp. 141-142.

4. Idem.

5. Kęstutis Šapoka, „Pokalbis su Arūnu Dikčiumi», (Ne)priklausomo šiuolaikinio meno istorijos, op. cit., p. 151.

6. Jauna muzika, op. cit., p. 123.

7. Kęstutis Šapoka, „Pokalbis su Arūnu Dikčiumi», (Ne)priklausomo šiuolaikinio meno istorijos, op cit., p. 151.

8. Živilè Ramoškaitè, «Akcijos ir opusai», Druskininkų pavasariai ir muzika, 1985-2014 (Edited by Urbietytė-Urmonienè), Vilnius: Lietuvos muzikos ir teatro akademija, 2014, pp. 176-177.

9. Kęstutis Šapoka, „Pokalbis su Arūnu Dikčiumi», (Ne)priklausomo šiuolaikinio meno istorijos, op cit., pp. 150-151.

10. Popper, Frank. Art, action et participation, Paris, Klincksieck, 1985.

11. Kabelis, Ričardas (Ed.). Jauna muzika, [Vilnius, Lietuvos kompozitorių sąjunga], 1989.

12. Michelkevičius, Vytautas, Šapoka, Kęstutis (Ed.). (Ne)priklausomo šiuolaikinio meno istorijos, Vilnius: LTMKS, 2011.

13. Urbietytė-Urmonienė, Vaida (Ed.). Druskininkų pavasariai ir muzika, 1985-2014, Vilnius: Lietuvos muzikos ir teatro akademija, 2014. 


\section{Вита Груодите Фестивахи современной музыки в Аитве: от действия - к концепции}

Аннотация. Обретение Аитвой в 90-х годах независимости в истории Аитовской музыки ознаменовалось коротким, но очень важным периодом, который вызвал появцение новых междисциплинарных подходов - хепенинга, акционизма и перформанса. Эта новая волна, инициированная молодыми композиторами и музыковедами, пыталась обозначить разрыв с эстетикой, навязанной советской идеологией, Ааже когда та перестала быть господствующей.

Ключевые слова: митовская музыка, хепенинг, акционизм, перформанс, фестивали современной музыки.

\section{Віта Груодіме Фестивалі сучасної музики в Аитві: від Аї̈ - до концепції}

Анотація. Набуття Аитвою в 90-х роках незалежності в історії Аитовської музики ознаменувалося коротким, але дуже важхивим періодом, який спричинив появу нових міждисциплінарних підходів - гепенінгу, акционізму та перформансу. Ця нова хвиля, ініційована молодими композиторами і музикознавцями, намагалася окреслити розрив з естетикою, нав'язаною радянською ідеологією, навіть тоді, коли вона вже не була панівною.

Ключові слова: митовська музика, гепенінг, акционізм, перформанс, фестивалі сучасної музики. 